\title{
Viri Militares Moving from West to East in Two Crisis Years (AD 133 and 162) ${ }^{1}$
}

\author{
Anthony R. Birley
}

\section{Introduction}

Something needs to be said about the term viri militares. Livy applied the term to Laelius and other men on Scipio's staff, to whom the general awarded decorations. ${ }^{2}$ Sallust uses the term homines militares for two praetors of 63 вс. ${ }^{3}$ His prime example of a homo militaris is M. Petreius, who had "won great glory in the army for more than thirty years as tribune or legate or praetor." Tacitus seems to have applied the term to men of lower rank, when lamenting how under Domitian "so many armies had been lost, in Moesia and Dacia, in Germany and Pannonia, by the folly or cowardice of their generals, so many military men, with so many cohorts, had been defeated in battle and taken prisoner." ${ }^{5}$

Augustus' reform of the political and military system reduced the opportunities for lengthy service and of course for winning glory. Corbulo had been up against the changed conditions under Claudius, and is said by Tacitus to have reacted to the emperor's ban on his campaigning beyond the Rhine by sighing

1 This paper is a postscript to A.R. Birley, 'Two governors of Dacia Superior and Britain', in V. Iliescu, D. Nedu, A.-R. Barboş, eds., Graecia, Roma, Barbaricum. In Memoriam Vasile Lica (Galati 2014), 241-59, where it is shown that the Hadrianic expeditio Brittannica named in two inscriptions must refer to Hadrian's visit to Britain in AD 122; and that the careers of the two officers known to have served in it (ILS 2726 and 2735) cannot be taken to prove that there was a 'second war' in the island during his reign, as is still claimed.

2 Liv. 30.15.13: Laelium deinde et ipsum conlaudatum aurea corona donat; et alii militares viri (...) donati.

3 Sall. Cat. 45.1.

4 Sall. Cat. 59.6: homo militaris, quod amplius annos triginta tribunus aut legatus aut praetor magna gloria in exercitu fuerat.

5 Tac. Agr. 41.2: tot exercitus in Moesia Daciaque et Germania et Pannonia temeritate aut per ignaviam ducum amissi, tot militares viri cum tot cohortibus expugnati et capti. 
that "Roman generals were fortunate in former times!"6 Tacitus comments that his father-in-law was aware that "a great reputation was no less dangerous than a bad one."

Rome's armed forces in the Principate were based around the periphery and the empire had no mobile field army. Hence it was necessary to move legions and other units from one front to another when a crisis erupted. What was intended to be temporary sometimes became permanent redeployment. Simultaneous wars on two fronts created major problems. Not till the later second century did it become normal practice to send detachments, vexillationes, instead of whole legions, from one army to another, for the duration of a campaign. All these movements and transfers were documented eighty years ago in the great encyclopaedia article by Emil Ritterling, still basic, although requiring modification from time to time. ${ }^{8}$ As for the auxilia, these smaller but much more numerous units were regularly moved back and forth. Details about their whereabouts now constantly require updating, mainly because of the incessant flood of new diplomas unearthed through metal-detecting. ${ }^{9}$ The great wars of Trajan's reign made frequent transfers necessary. ${ }^{10}$ Meanwhile the 'Who's Who' of the equestrian officers, edited (in Latin) by Hubert Devijver, has made it far easier to keep track of this important group. ${ }^{11}$ The new diplomas

6 Tac. Ann. 11.20.2: beatos quondam duces Romanos. The aborted campaign is described ibid. 18.1-20.1.

7 Tac. Agr. 5.4; cf. ibid. 17.2 on Frontinus, "a great man insofar as was permitted", vir magnus, quantum licebat; and 39.2, "good generalship was a quality reserved for the emperor", ducis boni imperatoriam virtutem esse.

8 E. Ritterling, art. 'Legio', Realencyclopädie der classischen Altertumswissenschaft 12.1 (1924), 1211-1328; 12.2 (1925), 1329-1829. The two volumes edited by Y. Le Bohec and C. Wolff, Les légions de Rome sous le Haut-Empire. Actes du Congrès de Lyon (17-19 septembre 1998) (Paris 200o), devote 754 pages to revising Ritterling.

$9 \quad$ More of these have been published by Werner Eck than by anyone else. One must also single out the invaluable series of supplements to the $C I L 16$ collection, Roman Military Diplomas, abbreviated RMD: 1 (1978), 2 (1985), 3 (1994), ed. M.M. Roxan; 4 (2003), edd. eadem and P. Holder; 5 (2006), ed. P. Holder, all London. Volume 6, ed. P. Holder, is nearing completion.

10 As an example of the astonishing quantity of information that can be gained from diplomas one may cite P.A. Holder, 'Auxiliary deployment in the reign of Trajan', Dacia n.s. $5^{0}$ (2006), 141-174. Note here, his citing at p. 154, cf. 144, an ala, listed in AD 114 as missa in expeditionem from the army of Pannonia inferior; and at p. 143, discussing cohorts listed in the army of Moesia superior in AD 114 as translatis in expediti[one]. His discussion of the subsequent deployment of these units is instructive.

11 This work, the Prosopographia Militiarum Equestrium quae fuerunt ab Augusto ad Gallienum, here abbreviated $P M E$, is in six volumes: 1 (A-I, 1976), 2 (L-V, 1977), 3 
have also produced a great deal of extra information about suffect consuls and provincial governors, particularly for the period from Trajan to Antoninus Pius. $^{12}$

For officers of both senatorial and equestrian rank it was normal to move from province to province: detailed careers where known show for the most part that senators and knights, especially the former, served in different armies at successive stages; for both there was a certain regularity in the career structure. This is more obvious with the equites Romani, for whom the stages were in due course labelled the tres militiae; and later there was the quarta militia as well. ${ }^{13}$ The provinces governed by legati Augusti pro praetore did not have similar ranking designations. In the Julio-Claudian period, when the imperial provincial system was still developing, one cannot detect real regularity in the appointment of governors. It is striking how Tacitus records how Nero tackled the sudden crisis in the east shortly after his accession. His initial measures, guided by his advisers Burrus and Seneca, were carefully watched, and approved, and "there was delight among the senators that he had appointed Domitius Corbulo to take charge of holding onto Armenia and that room

(Indices, 1980), 4 (Suppl. 1, 1987), 5 (Suppl. 2, 1993), 6 (laterculi of units, 2001), all published at Leuven. Volume 6, the 'laterculi alarum cohortium legionum', edited by Ségolène Demougin and Marie-Thérèse Raepsaet-Charlier, appeared four years after Devijver's death in 1997. A minor irritation is that Devijver declined to repeat in his $P M E$ the career details of the more than 130 officers covered in his 'trial run', De Aegypto et exercitu Romano sive Prosopographia Militiarum Equestrium quae ab Augusto ad Gallienum seu statione seu origine ad Aegyptum pertinebant. Studia Hellenistica 22 (Lovanii 1975), giving only simple cross-references. Cf. n. 46 below for an example.

12 This is an appropriate place to register the publication in autumn 2015 of the final volume of $P I R^{2}$, Pars VIII Fasciculus 2, most of it covering persons whose names began with V, as well as a handful of names beginning $\mathrm{X}$ and $\mathrm{Z}$. The first volume of the second edition, covering A and B, of this indispensable work appeared in 1933, under the editorship of Edmund Groag and Arthur Stein. Due tribute must be paid to those who kept the great work going in extraordinarily difficult times and have brought it to completion after 82 years.

13 Still basic is E. Birley, 'The equestrian officers of the Roman army', first published in the Durham University Journal (December 1949), 8-19, repr. in idem, Roman Britain and the Roman Army. Collected Papers (Kendal 1953), 133-53; and again, rev. in idem, The Roman Army. Papers 1929-1986 (Amsterdam 1988), 147-65. See also idem, 'Beförderungen und Versetzungen im römischen Heere', Carnuntum Jahrbuch 1957 (Wien 1958), 3-20, and the revised version of that paper, 'Promotions and transfers in the Roman Army: senatorial and equestrian officers', in idem 1988, op. cit., 93-114, at 105-13. 
seemed to have been cleared for virtues."14 One might render virtutes here as 'merit', as opposed to corruption.

In the later first century and above all in the period from Trajan to the Antonines, patterns of promotion for senators in the emperors' service assumed a certain regularity. The number of imperial provinces governed by ex-praetors gradually increased with the annexation of new territory and the change in status, or subdivision, of existing provinces. Further one-legion provinces in which the legate of the legion was also the governor, were: Judaea, from 70 until c. 117; Arabia from Trajan onwards; Pannonia inferior from Trajan to Caracalla; Dacia superior, from Hadrian to Marcus Aurelius; Raetia and Noricum under Marcus Aurelius; Syria Phoenice under Severus; Britannia inferior from Caracalla onwards. There were never more than six of these one-legion provinces at any one time. Before Marcus Aurelius only one case is known of a man governing two praetorian imperial provinces, Pompeius Falco under Trajan. In the 16os and 170s, perhaps due to a shortage of qualified expraetors after war and plague, more can be identified; further examples are found in the third century.

Most legati Augusti pro praetore of consular status governed provinces with more than one legion. Exceptions were the very large province of Hispania Tarraconensis, still governed by an ex-consul after its garrison was reduced to one legion in the 7os; Dalmatia, which under Trajan regained a consular governor after losing its legionary garrison; and Pontus-Bithynia, which was originally governed by praetorian proconsuls, and never had a legionary garrison, but from Marcus Aurelius onwards was assigned to consular legates. All the consular imperial provinces could be governed by recent ex-consuls, but Tarraconensis, Britain and Syria, later also the 'Three Dacias' (after they were reunited in the 16os), were mostly assigned to men who had previously governed one of the other consular provinces, namely the two Germanies, the two Moesias, Upper Pannonia, Cappadocia, and Syria Palaestina. Although two of these 'junior' consular provinces, Upper Pannonia and Lower Moesia, for much of the Principate had as many legions, three, as did Britain, Syria and the Three Dacias, they were less exposed to external threat. As for Tarraconensis, its great prestige as one of Rome's oldest and largest provinces no doubt meant that senior men were glad to govern it. The length of tenure depended on the emperor. Most probably served for about three years. Patronage and bribery

Tac. Ann. 13.8.1: praeter suetam adulationem laeti, quod Domitium Corbulonem retinendae Armeniae praeposuerat, videbaturque locus virtutibus patefactus. Cf. A.R. Birley, Locus virtutibus patefactus? Zum Beförderungssystem in der Hohen Kaiserzeit. RheinischWestfälische Akademie der Wissenschaften. Vorträge G 318 (Opladen 1992). 
probably played less of a role with the most senior posts than at lower levels. The emperors and their advisers generally kept to their own 'rules'. Not least, a fairly standard order of seniority for provincial commands can be observed for those who governed more than one province after their consulship..$^{15}$ Very few men governed more than two consular provinces, although exceptions are found at times of serious warfare. ${ }^{16}$ But after one or more consular commands in the emperors' service, most senators could look forward only to a year as proconsul of Africa or Asia.

Two second-century governors who moved from one end of the empire to the other in unusual career moves deserve highlighting. Both recall the appointment of Corbulo to his special command in the east in AD 54, but no literary source resembling Tacitus survives to describe the contemporary reactions. In the early 130s, Sextus Julius Severus (cos. 127) was summoned to Judaea by Hadrian, from Britain, where he was governor, to suppress the revolt of Bar Kochba, as specifically recorded by Cassius Dio. Judaea, which had only recently become a two-legion province, thus gained an ex-consul as governor; but it was not a 'normal' posting to follow the command of a threelegion province, such as Britain. ${ }^{17}$ Almost thirty years later the Parthians, who had been threatening war in the last months of Antoninus Pius' reign, invaded the empire. ${ }^{18}$ The result was a disaster for Rome at Elegeia: according to Dio it

15 See e.g. E. Birley, 'Senators in the emperors' service', Proceedings of the British Academy 39 (1954), 197-214, repr. in idem 1988, op. cit. (n. 13), 75-92; and idem 1988, op. cit. (n. 13), 93-105; W. Eck, 'Beförderungskriterien innerhalb der senatorischen Laufbahn, dargestellt an der Zeit von 69 bis 138 n. Chr.', Aufstieg und Niedergang der römischen Welt 2.1 (Berlin and New York 1974), 158 ff.; G. Alföldy, Konsulat und Senatorenstand unter den Antoninen. Prosopographische Untersuchungen zur senatorischen Führungsschicht (Bonn 1977); A.R. Birley, The Fasti of Roman Britain (Oxford 1981), 3 ff.; idem 1992, op. cit. (n. 14), passim; idem, The Roman Government of Britain (Oxford 2005), $3 \mathrm{ff}$.

16 A list is given by A.R. Birley, 'Senators as generals', in G. Alföldy, B. Dobson, and W. Eck, eds., Kaiser, Heer und Gesellschaft in der Römischen Kaiserzeit. Gedenkschrift für Eric Birley. Heidelberger althistorische Beiträge und epigraphische Studien 31 (Stuttgart 2000), 97-119, at 111-114.

17 As Gaius Julius Severus from Ankara was also active in the same theatre of war at this time, as legate of the Syrian legion IV Scythica and then as acting governor of Syria $\left(P I R^{2} \mathrm{~J}\right.$ 573), the man who defeated the Jewish rebels is here called Sextus Julius Severus throughout-even if he changed his name in the 130s, see below.

HA, M. Ant. Phil. 8.6: fuit eo tempore etiam Parthicum bellum, quod Vologessus paratum sub Pio Marci et Veri tempore indixit. The dispatch by Antoninus Pius of the legate of the Syrian legion XVI Flavia fidelis, L. Neratius Proculus, "to lead detachments into Syria because of the Parthian war", took place at the very end of Pius' reign, as shown by P. Weiß, 'Militärdiplome und Reichsgeschichte: Der Konsulat des L. Neratius Proculus und 
involved the destruction of a legion with all its officers and the suicide of the Cappadocian legate, M. Sedatius Severianus (cos. 153), called by Lucian "that stupid Celt" (stupid because he had fallen under the influence of Alexander the false prophet of Abonuteichos, a Celt because he was from Poitiers). ${ }^{19}$ To tackle the new eastern crisis, the man who was clearly recognised by Marcus Aurelius and Lucius Verus as their most competent general, M. Statius Priscus (cos. ord. 159), was summoned from Britain, shortly after he had arrived there. Each of these governors evidently took selected officers with them. In both cases the emperor of the day chose as commander to deal with the crisis men who were at the opposite end of the empire, surely a sign that the best qualified military man of the time was generally assigned to govern Britain. Sextus Julius Severus had, further, already had at least fifteen years of service in the Roman army when chosen, Statius Priscus only slightly less, albeit his first five years had been as an equestrian officer. ${ }^{20}$ In both cases, the senators and the informed public may well have applauded the choice with the comment: locus virtutibus patefactus.

\section{Hadrian's Dispatch of Sextus Julius Severus to Judaea}

The general's most detailed epigraphic career record is on a statue-base from Burnum in Dalmatia (his home town was Aequum in that province). He was still named Sextus Julius Severus when cos. suff. in 127, but, after presumed adoption by Gnaeus Minicius Faustinus (cos. suff. 117) —or following an inheritance from this man with the condicio nominis ferendi-at the start of the Burnum inscription he was styled $[$ Cn. $(=$ Gnaeo $)]$ Minicio Faustino $[[u l i] o[\ldots f]$

die Vorgeschichte der Partherkriegs unter Marc Aurel und Lucius Verus', in R. Haensch and J. Heinrichs, eds., Herrschen und Verwalten. Der Alltag der römischen Administration in der Hohen Kaiserzeit. Kölner Historische Abhandlungen 46 (Köln and Weimar), 160-172, at 161-172. This action by Proculus was previously dated to a much earlier point in the reign.

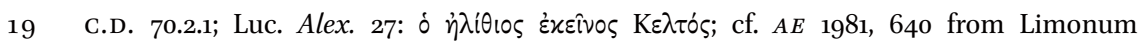
Pictavorum, clearly his home town. See on his career esp. I. Piso, Fasti Provinciae Daciae I. Die senatorischen Amtsträger (Bonn 1993), 61-65, with addenda and corrigenda in idem, Fasti Provinciae Daciae I. Die ritterlichen Amtsträger (Bonn 2013), 35-37. Severianus had governed Dacia superior from AD 150 or 151 to 153 .

20 A.R. Birley 2000, op. cit. (n. 16), 111, gives a short list of senators who had had between 12 and 21 years of military service. 
il(io) Serg(ia) Severo: "To Gnaeus Minicius Faustinus Julius, son of [Sextus?], (in the) Sergia (voting-district), Severus."21

His special appointment to Judaea is specifically registered in a fragment from Dio: "Then indeed Hadrian sent his best generals against them, foremost among whom was Julius Severus, who was dispatched from Britain, of which he was governor, against the Jews."22

This is not the place to discuss the man's earlier career in detail, although it is remarkable in many ways. ${ }^{23}$ The present paper concerns his transfer from Britain to Judaea. His dates can now be refined in the light of two new diplomas: one shows him already governor of Britain in AD 130, the other reveals that he was still there on 9 December $132 .{ }^{24}$

Sextus Julius Severus seems to have taken at least two equestrian officers with him from Britain to Judaea. Three or four centurions may also be supposed to have transferred with him at this time. But before discussing these cases, it should be noted that he may have taken with him to Judaea a whole legion, IX Hispana, although it is uncertain whether it was still in Britain when he was governing the province. IX Hispana was once thought to have been destroyed in Britain early in Hadrian's reign, when there were certainly heavy Roman losses there. ${ }^{25}$ But consideration of the careers of several of its officers has made this hardly plausible: there are three former tribuni laticlavii whose service in it should be significantly later than the years 117-119, and a legate $\mathrm{L}$. Aninius Sextius Florentinus, who, after commanding IX Hispana, became proconsul of Narbonensis, then governor of Arabia, where he is attested in 127, so is unlikely to have left the legion much before $124 .{ }^{26}$ This leaves unresolved the moment of the legion's own departure from Britain. Its latest datable record

21 CIL 3. $2830=9891=I L S$ 1056. O. Salomies, Adoptive and Polyonymous Nomenclature in the Roman Empire (Helsinki 1992), 126, n. 108, convincingly argues that Sex(to), his original praenomen, although generally restored after Faustino, would have been omitted here. His filiation at this time remains uncertain.

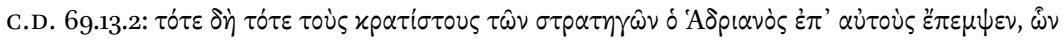

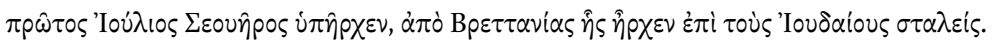

23 See especially Piso 1993, op. cit. (n. 19), 42-4, updated in idem 2013, op. cit. (n. 19), 24-29; A.R. Birley 2005, op. cit.(n. 15), 129-132; see Eck this volume 109-110.

$A E$ 2006, 1836; 2010, 1856. The second one gives Hadrian the title proco $(n) s(u l)$. This indicates that the emperor had delayed his return to Italy until 133 because of the Jewish uprising and - what has often been denied — that he actually spent some time at the front.

25 See e.g. A.R. Birley, 'A new tombstone from Vindolanda', Britannia 29 (1998), 299-306.

26 For the tribunes, A.R. Birley 2005, op. cit. (n. 15), 286-7, 256-7; for the legate, 244. 
there is an inscription of AD 108 at York. ${ }^{27}$ Its whereabouts thereafter are uncertain, but it could have been taken to the east initially to fight in the Jewish war, from 133 to 136, after which it could have been transferred to Cappadocia. A possible date for that (final) move is AD 137. Even if no further trouble was expected from the Alani, against whose threatening movements the historian Arrian (Flavius Arrianus) had been active as governor of Cappadocia in 135, as his Ektaxis set out in detail, he could well have urged Hadrian to reinforce the province. ${ }^{28}$ The disappearance of IX Hispana could then conjecturally be assigned to the disaster at Elegeia in 161, when, as mentioned above, an unnamed legion of the Cappadocian army was destroyed with all its officers, and the governor Sedatius Severianus took his own life. ${ }^{29}$

As the Burnum inscription shows, Sextus Julius Severus conducted the campaign with success, receiving the highest military honours open to a senator, the ornamenta triumphalia. Dio's account, preserved in epitome, ${ }^{30}$ gives some details of his operations. He suppressed the rebels with relentless efficiency, picking them off in small groups. He destroyed "fifty of the Jews' most important outposts and 985 of their most famous villages"; and 580,000 men are said to have been killed on the Jewish side. Dio does not record Roman casualties, which were substantial. ${ }^{31}$

Among those who served under him one may note three future governors of Britain: Q. Lollius Urbicus, legatus imp(eratoris) Hadriani in expedition(e) Iudaica, who may be regarded as the general's 'chief of staff'; probably the general's son Cn. Julius Verus as tribunus laticlavius of X Fretensis; and M. Statius Priscus, then just prefect of a cohort. ${ }^{32}$ Sextus Julius Severus no doubt remained

$27 \quad$ RIB 665.

28 On Arrian's career still instructive is R. Syme, 'The career of Arrian', Harvard Studies in Classical Philology 86 (1982), 181-212, repr. in idem, Roman Papers 4 (Oxford, 1988), 21-49, esp. 200-202 $=38-40$.

29 IX Hispana is omitted from the register of legions drawn up not long before c. 165, ILS 2288, Rome. On its possible history under Hadrian and later, A.R. Birley 2005, op. cit. (n. 15), 228-9, with detailed references to earlier discussions. The identification of the unnamed legion with IX Hispana is approved by Piso 1993, op. cit. (n. 19) 64 with his n. 15 .

30 C.D. 69.13.3-14.1.

31 W. Eck, 'The Bar Kokhba revolt: the Roman point of view', Journal of Roman Studies 89 (1999), 76-89, underlines the seriousness of the war for Rome and of Rome's losses, including not only the legio XXII Deiotariana but numerous auxiliary units. See further, among his numerous important contributions on this subject, W. Eck, 'Der Bar Kochba Aufstand der Jahre 132-136 und seine Folgen für die Provinz Judaea/Syria Palaestina', in G. Urso, ed., Iudaea Socia-Iudaea Capta (Milan 2012), 249-265.

A.R. Birley 2005, op. cit. (n. 15), 136-140; 145-9; 151-5. 
in Judaea until the war was ended, in $136 .{ }^{33} \mathrm{He}$ was then apparently appointed to yet another governorship, of Syria, although this has been doubted; if it is accepted, this is further evidence for the satisfaction with which Hadrian regarded him. ${ }^{34}$ At all events, the distinguished career in the emperors' service of his son Julius Verus, indicates that imperial favour for this family of colonial Romans continued into the next two reigns. ${ }^{35}$

As for the men whom Sextus Julius Severus probably took with him from Britain to Judaea, to start with one may discuss two equestrians. The first was the future great commander of the $160 \mathrm{~s}$, M. Statius Priscus Licinius Italicus (cos. ord. 159), in the early 13os still only a Roman knight, in his prima militia as prefect of a cohort. For convenience the inscription setting out his complete career in descending order, may be cited here, as the later stages will be discussed in the second part of this paper:

[M(arco) Stati]o M(arci) f(ilio) Cl(audia) Prisco [L]icinio Italico, leg(ato) Augustorum $\operatorname{pr}(\mathrm{o}) \operatorname{pr}($ aetore $) \operatorname{prov}($ inciae) Cappadociae, leg(ato) Aug[g.=Augustorum duorum)] pr(o) pr(aetore) prov(inciae) Brittanniae, $\operatorname{leg}$ (ato) $\operatorname{Aug}[\mathrm{g} .=$ Augustorum duorum) $] \operatorname{pr}(\mathrm{o}) \operatorname{pr}$ (aetore) $\operatorname{prov}($ inciae $)$ Moesiae super(ioris), curato[ri] alvei Tiberis et cl[o]acarum urbis, c[o(n)s(uli)], leg(ato) Aug(usti) prov(inciae) Daciae, leg(ato) leg(ionis) XIII G(eminae) p(iae) f(idelis), leg(ato) leg(ionis) [X]IIII Gem(inae) Martiae Victricis, sacerdoti Titiali [Fl]aviali, pr(aetori) inter cives et peregrinos, $\operatorname{tr}(\mathrm{ibuno}) \mathrm{pl}(\mathrm{ebis})$, quaes[t(ori)], proc(uratori) Aug(usti) XX (Vicesimae) hereditatium prov(inciarum) Narbone(n)s(is) et Aquita[n(iae), p]r(aefecto) eq(uitum) alae I pr(aetoriae) c(ivium) $\mathrm{R}$ (omanorum), $\operatorname{tr}$ (ibuno) mil(itum) leg(ionis) I Adiutr(icis) p(iae) f(idelis) et leg(ionis) X [G(eminae)] p(iae)[f(idelis) e]t leg(ionis) IIII (sic: a mistake for III) Gallicae, praef(ecto) coh(ortis) IIII Lingonum, vexillo mi[l(itari) d]onato a divo Hadriano in expeditione Iudaic[a], Q(uintus) Cassius Domitius Palumbus.

33 For the date, $\mathrm{AD} 136$, rather than 135 as previously thought, see W. Eck 1999, op. cit. (n. 31).

34 Attested only by $I L S$ 1056; omitted in $P^{2} R^{2} \mathrm{~J} 576$; accepted by E. Dąbrowa, The Governors of Roman Syria from Augustus to Septimius Severus (Bonn 1998), 96. Werner Eck, as he kindly tells me, regards the governorship of Syria as non-existent, resulting from a confusion caused by the renaming of Judaea as Syria Palaestina after the war ended.

35 A.R. Birley 2005, op. cit. (n. 15), 145-9: after active service under Antoninus Pius, he was prominent under Marcus, both in the Parthian war of the 160 and the Marcomannic war of the 170s; he died in 179, having been designated to a second consulship, as ordinarius, for 180 . 
(In honour of) Marcus Statius, son of Marcus, (in the) Claudia (votingdistrict), Priscus Licinius Italicus, propraetorian legate of the emperors of the province Cappadocia, propraetorian legate of the two emperors of the province Brittannia, propraetorian legate of the two emperors of the province Moesia superior, curator of the bed of the Tiber and of the sewers of the City, consul, propraetorian legate of the emperor of the province Dacia, legate of the legion XIII Gemina Pia Fidelis, legate of the legion XIIII Gemina Martia Victrix, Titial Flavial priest, praetor (dealing with disputes) between citizens and foreigners, tribune of the plebs, quaestor, procurator of the emperor for the five per cent inheritance tax in the provinces of Narbonensis and Aquitania, prefect of cavalry of the Ala I Praetoria, military tribune of the Legion I Adiutrix Pia Fidelis and of the Legion X Gemina Pia Fidelis and of the Legion IIII [sic: a mistake for III] Gallica, prefect of the Cohors IIII Lingonum, decorated with a military flag by the Deified Hadrian in the Jewish expedition, (set up by) Quintus Cassius Domitius Palumbus. ${ }^{36}$

The inscription gives Priscus' first post as prefect of the Fourth Cohort of Lingones, known to have been stationed in Britain, ${ }^{37}$ and registers that for service 'in the Jewish expedition' he received a decoration from Hadrian. He did not necessarily take his cohort to Judaea; more likely Sextus Julius Severus had him promoted to the militia secunda, first as tribune in the Syrian legion III Gallica, which took part in the war; Priscus probably held his second tribunate in a detachment of the Upper Pannonian legion X Gemina, which had been brought to Judaea by Sextus Attius Senecio. Since the third tribunate that followed was in another legion of Pannonia superior, it may be conjectured that he returned to that province with $X$ Gemina and was retained there, as tribune of I Adiutrix. ${ }^{38}$ After these three tribunates he finally entered the third

$36 \quad$ CIL 6. $1523=I L S$ 1092, Rome.

37 P.A. Holder, The Roman Army in Britain (London 1982), 119; M.G. Jarrett, 'Non-legionary troops in Britain: part one, the units', Britannia 25 (1994), 35-71, at 62, adding that "nothing suggests that he took the cohort [sc. to Judaea] with him." Contrast S. Applebaum, Prolegomena to the Study of the Second Jewish Revolt (Oxford 1976), 44-49; cf. his Appendix, 65-69, listing 24 cohorts and 8 alae which "served, or probably served in Hadrian's Jewish war", an interesting attempt, naturally requiring fundamental revision in the light of all the new diploma evidence.

38 H.-G. Pflaum, Les carrières procuratoriennes équestres sous le Haut-Empire romain (Paris 1960-1), hereafter cited as $C P$, no. 136, assumed that his tribunates of I Adiutrix and $X$ Gemina were the first two that he held and that they were both served in those legions' home province, Pannonia superior. Piso 1993, op. cit. (n. 19), 69 and n. 4, accepts that his 
militia, as prefect of an ala. This regiment, the Ala I Praetoria, was stationed in Pannonia inferior, at Teutoburgium, just beyond the confluence of the Dravus with the Danube. After this Priscus went on to a brief procuratorial career, with a rather lowly post, and then entry to the senate as quaestor. ${ }^{39}$ It is worth noting that his progress as a senator was very slow for the next two decades and it was only in the late 15 os that his career suddenly became spectacular, see below.

The second case of a man of equestrian rank evidently taken to Judaea, probably at this time, is conjectural. It concerns Marcus Censorius [C]ornelianus, known only from an altar he dedicated to Iuppiter Augustus at the fort of Maryport on the north-west coast of England:

Iovi Aug(usto) $\mathrm{M}$ (arcus) Censorius $\mathrm{M}$ (arci) fil(ius) Voltinia [C]ornelianus 7 (centurio) leg(ionis) [X Fr] etensis prae[fec]tus coh(ortis) I Hisp(anorum) ex provincia Narbone[n(si)] domo Nemauso [v.]s.l.m.

To August Juppiter, Marcus Censorius, son of Marcus, (in the) Voltinia (voting-district), Cornelianus, centurion of the Legion XFretensis, prefect of the First Cohort of Hispani, from the province Narbonensis, his home Nemausus, paid his vow willingly and deservedly. ${ }^{40}$

On this interpretation the equestrian officer, whose presence at Maryport can confidently be dated to Hadrian's reign, accepted a centurionate in the Jerusalem legion, prima facie a downgrading, but in fact a career move for which there are plenty of parallels. Whether he took part of the Cohors I Hispanorum with him is uncertain. ${ }^{41}$

first tribunate was in III Gallica, but assumes that his service in both the other two legions was in their home province. For the order proposed above, see Devijver, $P M E \mathrm{~S} 78$. Sextus Attius Senecio, tribune of $X$ Gemina, was "sent on the Jewish expedition by the deified Hadrian", with a detachment ( $C I L$ 6. 3505; PME A 188). On this interpretation, Statius Priscus' decoration, a vexillum, was gained for service as tribune, which would not usually have been sufficient for this rank, but it was in line with Hadrian's practice: see e.g. V.A. Maxfield, The Military Decorations of the Roman Army (London 1981), 176-7.

39 Pflaum, $C P$ no. 136, located the ala in Cappadocia, followed by Devijver, $P M E S$ 78, and others, including A.R. Birley 2005, op. cit. (n. 15), 153 and $P I R^{2}$ S 880 (published in 2006). It is corrected in PME 4 Supp. 1, p. 1726; see esp. B. Lörincz, Die römischen Hilfstruppen in Pannonien während der Kaiserzeit (Wien 2001), 206 and for Teutoburgium ibidem, 26.

$40 \quad$ RIB 814.

41 Jarrett 1994, op. cit. (n. 37), 47; PME C 106; D.J. Breeze, 'The regiments stationed at Maryport and their commanders', in R.J.A. Wilson, ed., Roman Maryport and its Setting. 
One may also postulate three or perhaps four centurions whose careers suggest that they went from Britain to Judaea at this time with Sextus Julius Severus:

1. Quintus Albius Felix, who served in the British legion $X X$ Valeria Victrix, was decorated by Hadrian, surely for service in the Jewish War:

\begin{abstract}
Q(uinto) Albio Q(uinti) f(ilio) Hor(atia) Felici, 7 (centurioni) leg(ionis) $\mathrm{XX} \mathrm{V(aleriae)} \mathrm{V(ictricis),} \mathrm{corniculario} \mathrm{pr(aefecti)} \mathrm{pr(aetorio),} \mathrm{donis}$ donato ab divo Traiano Aug(usto) torquibus armillis phaleris bello Parthico et ab imp(eratore) Caesare Traiano Hadriano Aug(usto) hasta pura et corona aurea. ${ }^{42}$
\end{abstract}

To Quintus Albius, son of Quintus, (in the) Horatia (voting-district), Felix, centurion of the Legion XX Valeria Victrix, adjutant of the Praetorian Prefect, decorated by the Deified Traianus with torques, arm-bands, discs in the Parthian War and by the Emperor Caesar Traianus Hadrianus with a pure spear and a gold crown.

2. Pon(...) Magnus is recorded from Hadrian's Wall sector 46-46b, in charge of a building party: [co]h(ortis) II 7 (centuria) Pon(...) Magni, datable a fortiori to the $120{ }^{43} \mathrm{He}$ is very likely the same man as Pontienus Magnus, chief centurion, $p$ (rimus) $p$ (ilus), of $X$ Fretensis in $\mathrm{AD} 150 .{ }^{44}$ One may infer that he was

Essays in Memory of Michael G. Jarrett (Kendal 1997), 67-89, at 73-75. For a quite different view, cf. E. Birley, 'A Roman altar from Old Kilpatrick and interim commanders of auxiliary units', Latomus 42 (1983) 73-83, at 78, repr. in idem 1988, op. cit. (n. 13), 221-31, at 226 , reading prae [posi] tus rather than prae [fec]tus: "(...) it is at least possible that the centurion in question, $\mathrm{M}$. Censorius Cornelianus, had come to Britain with a vexillation of X Fretensis, sent by Hadrian from Judaea expeditione Britannica (...) and he will, in that case, have been acting commander of the cohort." But this interpretation depends on E. Birley's frequently argued dating of the Hadrianic expeditio Brittannica to a later moment in Hadrian's reign, rather than to the time of Hadrian's own visit, sc. in AD 122: see now A.R. Birley 2014, op. cit. (n. 1), at 243-253, arguing that the expeditio must be dated to 122 , citing in particular M.G. Jarrett, 'An unnecessary war', Britannia 7 (1976), 145-151, R. Syme, 'Journeys of Hadrian', Zeitschrift für Papyrologie und Epigraphik 73 (1988) 159-170, at 165, repr. in idem, Roman Papers 6 (Oxford 1991), 346-57, at 353-4; and V. Rosenberger, Bella et expeditiones. Die antike Terminologie der Kriege Roms (Stuttgart 1992), passim. CIL 11. 3108. See Maxfield 1981, op. cit. (n. 38), 194-6.

43 RIB $1845^{+}$add.

44 CIL 16 App., no. 13; CPL no. 117, A 13 and B 9. 
taken to Judaea by Sextus Julius Severus, remained there, and was transferred to $X$ Fretensis, eventually becoming chief centurion of that legion.

3. Gaius Ligustinius Disertus:

C. (=Gaio) Ligustinio C. (=Gai) f(ilio) Clu(stumina) Diserto 7 (centurioni) leg(ionis) XX V(aleriae) V(ictricis), 7 (centurioni) leg(ionis) IIII Scyth(icae), item 7 (centurioni) leg(ionis) XX V(aleriae) V(ictricis) evocato Aug(usti), benef(iciario) praef(ecti) praet(orio) Eutyches lib(ertus) patrono optimo ob merita cuius dedicatione decurionib(us) et plebei crus $[\mathrm{tu}]$ lum et mulsum dedit. ${ }^{45}$

(In honour of) Gaius Ligustinius, son of Gaius, (in the) Clustumina (voting-district), Disertus, centurion of the Legion XX Valeria Victrix, centurion of the Legion IIII Scythica, likewise centurion of the Legion XX Valeria Victrix, retained in service by the Emperor, special duties man of the praetorian prefect, Eutyches (his) freedman (set this up) for his best of patrons on account of his deserts; on the occasion of the dedication he gave the decurions and plebs little cakes and honey-flavoured wine.

This man, after a full term (sixteen years) in the Praetorian Guard, during which he was a beneficiarius, 'special duties man', of the Prefect, had been invited to continue in the army as an evocatus Augusti, 'soldier retained in service by the Emperor'. He was then made a legionary centurion. ${ }^{46}$ His career in this rank consisted solely of two terms with the British legion $X X$ Valeria Victrix, interrupted by a commission in IV Scythica of the army of Syria. One may infer that his temporary move to the east could have been with Sextus Julius Severus (his cognomen meaning 'eloquent' is seemingly unique). ${ }^{47}$

45 CIL 11. 5960, Pitinum Mergens.

46 Disertus' origin at Pitinum Mergens was shared by a prefect of a cohort who served under the Hadrianic governor of Britain, L. Trebius Germanus, in office on 20 August AD 127: $R M D$ 4. 240 is a diploma issued to a veteran coh(ortis) II Lingon(um), cui prae(e)st C. Hedius Verus Pitino Merg(ente). Hedius Verus (PME H 2, with only a cross-reference to Devijver 1975 (op. cit. n. 11), no. 55) was later military tribune in the legion II Traiana fortis in Egypt and prefect of the Ala Indiana in Germania superior, as shown by CIL 11. 6123 , a statue-base at Forum Sempronii, of which he was patron. For the governor Trebius Germanus, see A.R. Birley 2005 (op. cit. n. 15) 125-129. One may speculate that it was he who appointed both men to posts in Britain.

47 See E. Birley, 'Promotions and transfers in the Roman Army II: the centurionate', Carnuntum Jahrbuch 1963-1964 (Wien 1965), 21-33, at 29f., repr. with some revision in idem 1988, op. cit. (n. 13), 206-20, at 216, accepted hesitantly by Maxfield 1981, op. cit. 
4. T. Quintius Petrullus. A partly preserved tombstone from Bostra in the province of Arabia commemorates a centurion of the Bostra legion III Cyrenaica, who died at the age of thirty and whose origin is registered as Britannia:

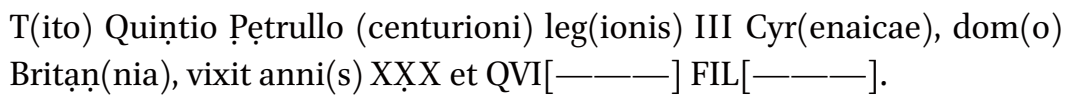

For Titus Quintius Petrullus, centurion of Legio III Cyrenaica, from Britain, who lived 30 years and.... ${ }^{48}$

In a forthcoming article three colleagues have plausibly suggested that Sextus Julius Severus' transfer from Britain to take command against Bar-Kochba could have been the occasion for Petrullus' becoming a centurion in Arabia. ${ }^{49}$ Of course, as they recognise, this can only be conjectural. One might note as a refinement the possibility that Petrullus came to the east as a soldier in the Ninth legion, if, as suggested above, it was brought to Judaea by Sextus Julius Severus, and that he was then offered a commission in III Cyrenaica. ${ }^{50}$

As a postscript on centurions, one may note that in contrast to the paucity of Greek cognomina among the Hadrianic centurions from the centurial stones along Hadrian's Wall, three of the Antonine centurions in Scotland have them: Sta(tilius?) Telesphorus, at Carriden, ${ }^{51}$ Antonius Aratus at Castlecary, ${ }^{52}$ and Glicon at Croy Hill. ${ }^{33}$ (The latter might of course be an officer in an auxiliary cohort.) It may be no more than coincidence, but if an explanation is required

(n. 38), 195-6. It need hardly be repeated that I respectfully reject E. Birley's frequently expressed theory, here in connection with Disertus, that there was "warfare again in Britain during the closing years of the reign". See $n .1$ above.

48 IGLS 13.1.9188+ add. (IGLS 13.2.9188), with H. Solin, 'Analecta epigraphica CCLXXXVCCXCI', Arctos 47 (2013), 265-300, at 281, cf. 275-6, who corrected the reading of the name. (It is not clear whether what follows et is qui or perhaps the start of a name).

49 L.E. Tacoma, T. Ivleva and D.J. Breeze, 'Lost along the way: a centurion domo Britannia in Bostra', Britannia 47 (2016), forthcoming. I am very grateful to the editor of Britannia, Professor Barry Burnham, and to the authors for allowing me to see their paper before publication and to cite it here.

$5^{0}$ One could also speculate that Petrullus had been offered a commission in III Cyrenaica before this, by L. Aninius Sextius Florentinus, the former legate of IX Hispana, when he became legate of Arabia (above, with n. 26), supposing that the legion had still been in Britain when Florentinus commanded it.

$51 \quad$ RIB 2138.

$5^{2} \quad R I B 2156$.

$53 \quad R I B 2164$. 
one might propose that on his move from Britain to Judaea Sextus Julius Severus may have taken not only a few officers from but whole units or detachments - the possible transfer of the legion IX Hispana has already been mentioned. Those units or detachments that later returned to Britain may have picked up new officers in the east, who came to Britain with them. Of course, Greek names do not always mean eastern origin. But for centurions in western legions this seems plausible.

For the transfer of a regiment from the Danube to the east under Hadrian, note the movement of coh(ors) I Claudia Sugambrorum veterana equitata from Moesia inferior to Eumeneia in Asia:

[....] divi Nervae nepotis Traiani Hadriani Aug(usti) domuique eiius senatui populiq(ue) $\mathrm{R}$ (omani) coh(ors) I Cl(audia) Sugambrum veteranae equitatae $\mathrm{M}$ (arcus) Iulius $\mathrm{M}$ (arci) f(ilius) Fab(ia) Pisonianus qui et Dion praef(ectus) fabrum et praef(ectus) coh(ortis) s(upra) s(criptae) domo Tyro metropolis Phoenices et Coeles Syriae qui a Moesia inf(eriore) Montan(a) praesidio numerum in Asia(m) perduxit v(otum) s(olvit) $\mathrm{l}$ (ibens) $\mathrm{m}$ (erito)

(In honour of the Emperor Caesar, son of the Deified Trajan), grandson of the Deified Nerva, Traianus Hadrianus Augustus, and his house and the senate and people of Rome, the First Claudian Cohort of Sugambrians, the Veteran one, part-mounted, (set this up). Marcus Julius son of Marcus, (in the) Fabia (voting-district), Pisonianus, who is also (called) Dion, Prefect of Engineers and Prefect of the above named Cohort, his home being Tyrus, the mother-city of Phoenice and Coele Syria, who led the unit from Moesia inferior from the station of Montana into Asia, fulfilled his vow willingly and deservedly. ${ }^{54}$

Eumeneia was probably just an intermediate stop—on the way to Judaea? (cos. ord. 159)

Priscus' early career has already been discussed in connection with Hadrian's Jewish War. Here, we may take a brief look at its later stages. His governorship of Dacia superior, attested by eight inscriptions in the province, as well as by 
his inscription at Rome, immediately preceded his consulship in 159. It is dated closely by diplomas, to 13 December 156 and 8 July 158 ; a dedication made at Apulum sub M. Statio Prisco consule designato can be assigned to autumn 158. Before that he had commanded the Carnuntum legion XIV Gemina, perhaps when Claudius Maximus, the friend of Marcus Aurelius, was governing Upper Pannonia (he is attested there in 150 and 154). Priscus' consulship as ordinarius for 159 was a remarkable honour for a novus homo - only one other man of comparable background, the great jurist Salvius Julianus, received similar distinction during this reign (he was consul ordinarius in AD 148). The obvious reason in Priscus' case was his military success in Dacia, presumably in fighting against free Dacians and Jazyges, as revealed by inscriptions from that province. ${ }^{55}$ It is worth asking whether the sudden rise in Priscus' fortunes, after his slow progress during most of the reign of Antoninus Pius, was the result of the change in the prefecture of the praetorian guard: M. Gavius Maximus, vir severissimus, died in AD 156 or 157 after nearly twenty years in that post, in which he doubtless exercised great influence on military appointments. ${ }^{56}$ After Priscus' consulship he was briefly Tiber curator, but before the end of 160 must have become governor of Moesia superior, where he is attested in office on 8 February 161. It may have seemed a good idea to put him back close to the region where he had won his victories in AD 158 . He was still there, not surprisingly, after the death of Pius in the following month, as shown by his dedication in honour of Marcus and Lucius Verus, set up after he had been appointed to Britain. It may have been the sudden death of a recently appointed governor of

$55 C I L$ 3. $1416=I D R$ 3. 3, 276, Sub Cununi, is a dedication by Priscus to Victoria Augusta, and the inscription from Apulum cited in the previous note was made "for the safety of the Roman Empire and the courage of the legion XIII Gemina under Marcus Statius Priscus, consul designate." Cf. $C I L$ 3. $1061=I L S 4006=I D R$ 3. 5, 185, Apulum. On his governorship of Dacia superior see Piso 1993, op. cit. (n. 19), at 7of., properly dismissing arguments from the wording of $I L S 1092$ that the governorship and command of the legion were separate. As he recognises, Piso 2013, op. cit. (n. 19) 36, the troops from Africa and Mauretania listed in the diploma of AD 158, CIL 16.108, can no longer be used as evidence for serious fighting under Priscus (as he had argued in 1993, 70 with n. 16, following earlier scholars), as they are now known to have been there earlier, citing $A E$ 2007, 1763 of AD 152. Indeed (as Paul Holder kindly points out) another new diploma shows that they were already there in AD 146: W. Eck and A. Pangerl, 'Zwei neue Diplome für die Truppen von Dacia Superior und Dacia Porolissensis', Zeitschrift für Papyrologie und Epigraphik 191 (2014) 269-277, at 271. The reason for this transfer remains uncertain.

56 On Gavius and his successors: HA, Antoninus Pius 8.7-9. See Pflaum, $C P$ no. 105 + Supp. pp. 32f., and no. 138. In particular, the entry into office of T. Furius Victorinus as prefect of the guard in AD 160, CP no. 139, may have been decisive for Priscus' consular appointments. 
Britain, or perhaps just the difficult military situation in the north of that province, that led the new co-emperors to transfer Priscus there soon after their accession. As stated by the Historia Augusta: "a British war was also threatening" at that time, which as it turned out had to be dealt with by Priscus' successor Sextus Calpurnius Agricola (cos. suff. 154). ${ }^{57}$

Priscus can only have spent some months at the most in Britain when a more serious situation arose in the east: a Parthian attempt to take control of Armenia, resulting in the defeat and suicide of the governor of Cappadocia, with the loss of a legion - perhaps it was IX Hispana (cf. above)—, then the Parthian invasion of Syria. Priscus was chosen to deal with this crisis, and won a major victory, capturing the Armenian capital Artaxata, ${ }^{58}$ and founding a new one, which he garrisoned. ${ }^{59}$ These successes allowed Verus, who had gone east in 162 as nominal commander-in-chief, to assume the title Armeniacus in 163. Lucian alleges that a contemporary historian described "how Priscus the general merely shouted out and twenty-seven of the enemy dropped dead."60 Hardly serious evidence, but perhaps Priscus had an aggressive style of leadership. The decision to summon Priscus from Britain to deal with a crisis in the east exactly parallels the sending of Sextus Julius Severus to Judaea a generation earlier. Severus was described as "the foremost of Hadrian's leading generals" in that connection. ${ }^{61}$ Priscus, after his success in Dacia in the late 150 , was no doubt equally highly rated. These two cases underline the high military status of Dacia and of Britain and their governors.

A rash previous speculation about Priscus' origin was that he might have come from the colonia of Camulodunum, Colchester in Britain; others had proposed Dalmatia or north-east Italy as his home. ${ }^{62}$ Now a newly discovered inscription, from Teanum Sidicinum, published in exemplary fashion by Giuseppe

HA, M. Ant. Phil. 8.7: imminebat etiam Brittanicum bellum. See A.R. Birley 2005, op. cit. (n. 15), $15^{-} 5$ on Priscus; $155^{-7}$ on Agricola.

$5^{8} \quad$ HA, M. Ant. Phil. 9.1, cf. Verus 7.1.

59 C.D. $71 \cdot 3 \cdot 1^{1}$.

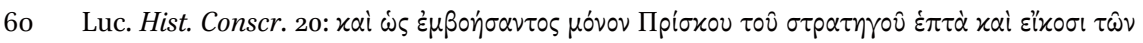
$\pi \circ \lambda \varepsilon \mu i \omega \nu$ ह่ $\xi \dot{\varepsilon} \theta \alpha \nu \circ v$.

61 C.D. 69.13 .2 , cited above, at n. 22.

62 Colchester: A.R. Birley 2005, op. cit. (n. 15), 152-3, with arguments rightly described as "un po' poco per fare di lui in pratica l'unico senatore romano di quella provincia," by G. Camodeca, 'Fufidia Clementiana, c(larissima) p(uella), e i suoi avi consolari in una nuova iscrizione da Teanum del tempo di M. Aurelio', Zeitschrift für Papyrologie und Epigraphik 179 (2011), 231-8 at 234-5. Cf. Alföldy 1977, op. cit. (n. 15), 314, suggesting Dalmatia, and for north-east Italy Piso 1993, op. cit. (n. 19), 73.
} 
Camodeca, has produced a rich harvest of prosopographical links-and a far likelier patria for the Statii, Luceria in Apulia. The text may be cited here:

Fufidiae Clemẹntianae, c(larissimae) p(uellae), L(uci) Fufidi Pol[1]ionis, c(larissimi) i(uvenis) fil(iae), L(uci) Fufidi Pollionis, co(n)sulis), nẹp(ti), Sex(ti) Corneli Clementis, co(n)s(ulis) ṇẹp(ti), M(arci) Stati Prisci, ducis eț co(n)s(ulis) prr[on(epti)], Cạpitolinus [se]r(vus) act(or).

(In honour of) Fufidia Clementiana, girl of senatorial rank, daughter of Lucius Fufidius Pollio, young man of senatorial rank, granddaughter of Lucius Fufidius Pollio, consul, granddaughter of Sextus Cornelius Clemens, consul, great-granddaughter of Marcus Statius Priscus, general and consul, Capitolinus, (her) slave agent (set this up).

This is engraved on a statue-base in honour of Priscus' great-granddaughter, Fufidia Clementiana, c(larissima) $p$ (uella), and names, as well as Priscus, described as ducis et cos., her father, L. Fufidius Pollio, c(larissimus) i(uvenis), her paternal grandfather, L. Fufidius Pollio (cos. ord. 166) and her maternal grandfather Sex. Cornelius Clemens (cos. suff. in the 16os). For the full discussion one must refer to Camodeca's paper. ${ }^{63}$ Here one may simply mention a few key points. Statius Priscus' son-in-law Fufidius Pollio, who served as legate of Galatia, clearly while Priscus was winning his victory in the adjacent Cappadocia and Armenia, no doubt owed his previously unexplained honour of being made consul ordinarius ${ }^{64}$ to his relationship to the great general. Since Priscus is not heard of again after his victory in AD 163, it may be that he died before the war ended. Perhaps the honour for his son-in-law was a way for the emperors to make up for the decorations which Priscus would have received at the triumph in October 166, had he lived. Further, the status of Cornelius Clemens in the family tree was clearly that of father-in-law of the younger Pollio, whose wife was probably called Cornelia Clementiana, as Camodeca infers from the name of the child honoured at Teanum. Clemens became governor of the III Daciae in AD 170, at a critical moment in the Marcomannic wars, following the death of M. Claudius Fronto (cos. suff. 165?), "fighting bravely for the commonwealth until the last", ad postremum pro $r(e) p($ ublica $)$ fortiter

63 Camodeca 2011, op. cit. (n. 62), passim. The inscription is reproduced as $A E 2011,271$.

64 Cf. Camodeca 2011, op. cit. (n. 62), 235-6, who cites Alföldy 1977, op. cit. (n. 15), 101ff., pointing out that the only other coss. ord. under Antoninus Pius and Marcus Aurelius not known to have come from consular families were the famous jurist P. Salvius Julianus (cos. ord. 148) —and Statius Priscus (cf. above). 
pugnans. ${ }^{65}$ Regarding the date of the dedication, one might suggest that the younger L. Fufidius Pollio was no longer alive at the time. He could well have died before he could enter the senate-perhaps a victim of the plague which was brought to Rome by the returning troops in 166 - and hence could only be called $c$ (larissimus) $i$ (uvenis). In that case, his daughter Clementiana was not necessarily just a child at the time of the dedication; although, as no husband is named, she was no doubt unmarried. Camodeca also draws attention to Fufidia Pollitta, probably an older sister of Fufidia Clementiana: Pollitta and her husband C. Caerellius Sabinus (cos. suff. ca. 190), are attested by several dedications in Dacia, where Sabinus was legate of legion XIII Gemina, based at Apulum. ${ }^{66}$ All in all, the Teanum inscription has thrown valuable light on the composition of the Roman high command at a critical time. ${ }^{67}$

As for the theme of this paper, it must be admitted that there is no hard evidence for men taken by Statius Priscus to Cappadocia. But there are a few possibilities. First, there is the remarkable M. Valerius Maximianus, whose career was made widely known by the statue-base in his honour found at Diana Veteranorum in Numidia. Here only the first few appointments require detailed comment. For convenience his career down to AD 175 is set out:

$\mathrm{M}(\operatorname{arco})$ Valerio Maximiano ... equo p(ublico), praef(ecto) $\operatorname{coh}($ ortis) I Thrac(um), trib(uno) coh(ortis) I (H)amiorum civium $\mathrm{R}$ (omanorum), praep(osito) orae gentium Ponti Polemoniani, don(is) don(ato) bello Phart(ico), allect(o) ab imp(eratore) $\mathrm{M}(\operatorname{arco})$ Antonino Aug(usto) et misso in procinctu Germanic(ae) exped(itionis) ad deducend(a) per

$65 C I L$ 6. $1377=31640=I L S$ 1098. See Piso 1993, op. cit. (n. 19), 94-102, and idem 2013, op. cit. (n. 19), 37-9, on Claudius Fronto, and 103-105, on Clemens.

66 See Piso 1993, op. cit. (n. 19), 235-7. The couple's dedication at Apulum to Iunoni Reginae Populoniae, deae patriae, CIL 3. $1075=I L S 3087=I D R$ 3.5, 107, coupled with Caerellius' tribe Oufentina, known from their son, C. Caerellius Fufidius Annius Ravus C. fil. Ouf. Pollittianus, $I L S$ 1160-1, had already pointed to Aquinum as his home town. The new inscription shows that his wife came from nearby Teanum: see Camodeca 2011, op. cit. (n. 62), 236-7.

67 The preceding remarks largely reproduce A.R. Birley 2014, op. cit. (n. 1), 255-8. One may still consult with profit R. Syme, 'Antonine government and governing class', Roman Papers 5 (Oxford 1988), 667-688, esp. 683-8. Note his suggestion, at 685, that as well as Statius Priscus "there was another ex-governor of Britain, Julius Verus, whom no literary source even names [who was] perhaps the chief architect of victory." Cn. Julius Verus (cos. c. 151, des. II 179) was governor of Syria in the early 160 s, his term of office probably beginning well before the only dated evidence, ILS 5864, of AD 164: $P I R^{2} \mathrm{~J}$ 618; Dąbrowa 1998, op. cit. (n. 34), 110-12; A.R. Birley 2005, op. cit. (n. 15), 145-9. 
Danuvium quae in annonam Panno(niae) utriusq(ue) exercit(uum) denavigarent, praepos(ito) vexillationum clas(sium) praetor(iarum) Misenatis item Ravennatis item clas(sis) Britannic(ae) item equit(um) Afror(um) et Mauror(um) elector(um) ad curam explorationis Pannoniae, praef(ecto) al(ae) I Aravacor(um), in procinctu Germanico ab imp(eratore) Antonino Aug(usto) coram laudato et equo et phaleris et armis donato, quod manu sua ducem Naristarum Valaonem interemisset et in eade $(\mathrm{m})$ ala quartae militiae honor(em) adepto, praef(ecto) alae contar(iorum), don(is) don(ato) bello Ger(manico) Sar(matico), praep(osito) equitib(us) gent(ium) Marcomannor(um) Naristar(um) Quador(um) ad vindictam Orientalis motus pergentium, honor(e) centenariae dignitatis [AD 175].

To Marcus Valerius Maximianus ..., (holder of) the public horse, prefect of the First Cohort of Thracians, tribune of the First Cohort of Hamii, Roman citizens, put in charge of the coast of the people of Polemonian Pontus, decorated in the Parthian War; chosen by the Emperor Marcus Antoninus Augustus and sent to the front in the German expedition to conduct along the Danube (goods) that were to move downstream to supply the armies of both Pannonias, having been put in charge of detachments of the praetorian fleets of Misenum and Ravenna and of the Britannic fleet, also of selected African and Moorish cavalrymen with the task of reconnoitering Pannonia; prefect of the Ala I Aravacorum, publicly praised by the Emperor Antoninus Augustus and awarded both a horse and discs and weapons because he had killed with his own hand Valao the chief of the Naristae, and in the same Ala achieved the rank of the fourth militia; prefect of the Ala Contariorum, decorated in the German-Sarmatian war, put in charge of cavalrymen from the peoples of the Marcomanni, Naristae and Quadi proceeding to punish the rising in the east, with the rank of a centenary (procurator). ${ }^{68}$

Maximianus began as prefect of a cohors I Thracum, followed by the tribunate of cohors I (H)amiorum civium $R$ (omanorum). There were at least three if not four cohortes I Thracum, so the identity of the one commanded by Maximianus cannot be verified. H.-G. Pflaum took it to be the one in Cappadocia, and accepted a very dubious Trier inscription as evidence for a milliary cohors I

$68 A E$ 1956. 124. See especially Pflaum, $C P$, no. 181 bis; and now $P I R^{2} V_{125}$. The Orientalis motus refers to the rebellion of Avidius Cassius. 
Hamiorum in Syria. ${ }^{69}$ Eric Birley suggested that Maximianus' militia prima was as prefect of the cohors I Thracum that was based in Britain, further, that "when Statius Priscus moved from Britain to take command in Cappadocia he took Maximianus with him." He rejected Pflaum's acceptance of the sixteenth-century reading of $c I L 13 \cdot 3684$, Trier, restored as commemorating a former centurion "of the First Milliary Cohort of Hamae(i) in Syria", [co]hortis [ $p] r$ (imae) Hamae(orum) miliariae in Syria. He preferred to restore "from the First Milliary Cohort of Thracians in Syria", ex [co]hort [ I I Tr $]$ ha [c(um) milliaria in Syria in the Trier inscription and concluded that this unit was irrelevant for Maximianus, whose command in the militia secunda as trib(unus) coh(ortis) $I$ (H)amiorum civium $R$ (omanorum) he preferred to locate in Cappadocia, assuming that there was a milliary cohort of Hamii in that province. ${ }^{70}$

But perhaps Maximianus had actually commanded the cohors I Hamiorum which is attested in Britain. This is after all the only cohors I Hamiorum for whose existence there is clear evidence, if one discounts the unit supposedly attested by the lost Trier inscription. An objection is that the British cohort was not a cohors milliaria, whereas the one that Maximianus commanded as tribune should prima facie have been of that size. However, it is worth noting that another presumed commander of the British quingenary cohort, Marcus Caecilius Donatianus, was "by the emperor's favour serving as a tribune (although still) a prefect", militans tribunus in praefecto dono principis, as he expressed it in his famous poem honouring the Dea Syria at Carvoran. ${ }^{71}$ Perhaps Maximianus had the same privilege-just as later, when praefectus

$69 \quad C P$, no. 181 bis.

$70 \quad$ E. Birley, 'Pannonians in Roman Britain', Zeitschrift für Papyrologie und Epigraphik 73 (1988), 151-5. The Trier inscription is known only from the 17 th century text by the antiquary Christophorus Brouwer of Arnhem. It is restored in CIL as follows (preceded by the words 'fuit fere'): Fl. Cor(nelio) Rufino 7 ex [co]hort $[e][p] r($ imae $) H a[$ m(iorum) miliariae in Syria, genito in Asia Trallis, defuncto Aug. Tr. [ann.] LV C Ll.] Afrania Valentina coniugi karissimo viva fecit. I offer the following version, which is closer to Brouwer's text: Fl. Gordio Rufino 7 coh $\mid$ ortis [ $p$ ]r(imae) Hamae(orum)] milliariae in Syria, genitus in Asia Trallis, defunctus Aug. Tr. [ann.] LV Cla(udia) Afrania Valentina coniugi karissimo viva fecit. J.E.H. Spaul, Cohors ${ }^{2}$. The Evidence for and a Short History of the Auxiliary Infantry Units of the Imperial Roman Army. British Archaeological Reports International series 841 Oxford 2000), 504, dismisses it as "a stone probably fourth century referring to a cohors Rhama whose one-time commander died in Germany." It must be noted that Rufinus was described as a centurion not as the commander of this cohort. Spaul does not list the coh. I (H)amiorum c.R. from AE 1956, 124 under the Hamii, but at 495 lists under 'cohortes incredibiles' Rhama milliaria. 
alae, he was granted the quartae militiae honor (em) before actually gaining the command of a milliary ala. ${ }^{72}$ Whether or not Maximianus did command the Carvoran cohort, it was back there under Statius Priscus' successor as governor of Britain, Calpurnius Agricola. ${ }^{73}$

If Maximianus brought a cohort, whether of the Thracians or of the Hamii, to Cappadocia and the Pontic shore, that would have involved him taking it across the North Sea, up the Rhine, across to the Danube, and down the river into the Black Sea. The experience would have stood him in good stead a few years later, when he had a special command, as praepositus vexillationum, 'put in charge of detachments', ad deducend (a) per Danuvium quae in annonam Panno(niae) utriusq(ue) exercituum denavigarent, "to conduct along the Danube (goods) that were to move downstream to supply the armies of both Pannonias." ${ }^{74}$

A further officer who might have been taken by Priscus from Britain to the east is recorded by a statue-base from Aesernia:

$\mathrm{P}$ (ublio) Septimio P(ublii) f(ilio) Tro(mentina) Paterculo praef(ecto) coh(ortis) I Pannoni[or(um)] in Brittania, praef(ecto) coh(ortis) [II] Hispanor(um) in Cappadoc(ia), flamini divi Traiani, patrono municipi, IIIIvir(o) i(ure) d(icundo), IIIIvir(o) quinq(uennali), q(uaestori) II, $\mathrm{d}($ ecurionum $) \mathrm{d}($ ecreto $)$.

(In honour of) Publius Septimius, son of Publius, (in the) Tromentina (voting-district), Paterculus, prefect of the First Cohort of Pannonians in Brittania, prefect of the Second Cohort of Hispani in Cappadocia, flamen of the Deified Traianus, patron of the municipium, quattuorvir iure

72 It is less of a difficulty that the British cohort is not recorded with the title $c . R$. attributed to the cohort commanded by Maximianus.

73 Under this governor, in office $c .162$ to 165 , their commander dedicated two altars at Carvoran: RIB 1792: Deae Suriae, sub Calpurnio Ag[r]ico[la] leg(ato) Au[g(usti)] pr(o) pr(aetore), Licinius [C]lem[ens, praef(ectus) co]h(ortis) I Ha[miorum]; and 1809, [... sub Calpurni]o Agricola, co(n)s(ulari), Licinius Cl[e]mens $p[$ raef(ectus). For Calpurnius Agricola's dates, A.R. Birley 2005, op. cit. (n. 15), 155-7. On the coh. I Hamiorum in Britain, see now A.R. Birley, 'The cohors I Hamiorum in Britain', Acta Classica 55 (2012) 1-16 (there not making this conjecture about Maximianus).

74 The interpretation put forward here differs in several respects from that of G. Alföldy, 'P: Helvius Pertinax und M. Valerius Maximianus', Situla 14/15 (1974), 199-215, repr. in idem, Römische Heeresgeschichte (Amsterdam 1987), 326-42, with Nachträge, 342-8. 
dicundo, quattuorvir quinquennalis, quaestor twice, (set up) by decree of the decurions. ${ }^{75}$

Eric Birley noted that " $[\mathrm{t}]$ he dating is evidently Hadrianic or later; but the fact of his move from Britain to Cappadocia, for his second posting in the militia prima, suggests to me the possibility that he was moved to the East by M. Statius Priscus, to take part in the Parthian war."76 Now that the origo of Statius Priscus has been shown to be at Luceria, and that of his close family at Teanum Sidicinum, it makes good sense if it was he who offered a further appointment as prefect of a cohort to a man from Aesernia.

One may also note the career of C. (Gaius) Julius C.(Gai) f(ilius) Ani(ensis) Seneca Licinianus, which has been assigned to the period " $c a$. $100-150$ ", so is perhaps a little too early; but the dating was based solely on lettering style. ${ }^{77}$ His move from being tribune of VIVictrix in Britain to tribune of XVApollinaris in Cappadocia could be explained by his commander-in-chief having been Statius Priscus. ${ }^{78}$

There are two more equestrian officers whose appointments in Cappadocia may have been owed to Statius Priscus, both of them men whom he may have met a few years before when serving as legate of Dacia superior. First, there is C.(Gaius) Porcius C.(Gai) fil(ius) Quir(ina) Saturninus Junior, who served in two tribunates, the first in Dacia, the second in Cappadocia. ${ }^{79}$ Then there is an ignotus, whose inscription registers that he held two posts in Cappadocia, as praef(ectus) coh(ortis)III Cyrenaicae and trib(unus) leg(ionis)XII Fulm(inatae). He was a leading citizen of Sarmizegetusa, the great colonia founded by Trajan..$^{80}$

\section{$4 \quad$ Conclusion}

Roman commanders have often been labelled 'amateurs', but that probably did not matter. They could rely on their junior officers, equestrians and centurions. But whereas in the Republic, especially in the age of Cicero and Caesar,

$75 \quad$ CIL 9. $2649=$ ILS 2732.

76 E. Birley, 1988, op. cit. (n. 70), 152, cited by Devijver, $P M E$ 5, Supp. 2, on S 36 . Spaul 20oo, op. cit. (n. 70), 334 dates the first post "c.a. 100"; Jarrett 1994, op. cit. (n. 37), 65: "later than 117”; neither cite E. Birley 1988, op. cit. (n. 70).

77 CIL 2. 6150, Barcino; G. Alföldy, Flamines provinciae Hispaniae citerioris (Madrid 1973), 75.

78 PME I 121.

$79 C I L$ 8. 1175, cf. p. 1386, Thuburbo Minus: trib. leg. XIII Gem. trib.leg. XII Fulm. See PME P 97.

8o $\quad A E$ 1971, 267, Alba Iulia. See PME Inc. 40. 
we are well informed about how Roman commanders chose their staff, this kind of information is not available in the imperial period. Governors of provinces with large armies had ample opportunity for patronage. Tribuni laticlavii were often enough sons or sons-in-law of the governors, who clearly appointed them. ${ }^{81}$ The governor also seems to have had a free hand in appointing equestrian officers and centurions. In AD 122, the earliest year for which the evidence for the garrison of Britain is almost or less complete, there were three (if not still four) legions in the province, each with one senatorial and five equestrian tribunes and 60 centurions, and a little over 50 auxiliary regiments commanded by equestrian officers. ${ }^{82}$ All these posts could in practice be filled by the governor, even if formal imperial approval was required. But the evidence suggests that governors normally could not nominate legionary legates. Dio singles out for comment as an anomaly that Corbulo was "so trusted [sc. by Nero] not to rebel that he even took his son-in-law to command a legion, even though he had not served as praetor." Otherwise than in the Julio-Claudian period, service as praetor had long before Dio's time become a normal qualification to command a legion. But Dio seems to have misunderstood the situation in any case: Corbulo's son-in-law, Annius Vinicianus, had clearly been commissioned as a military tribune and was, as Tacitus stated, only acting commander, pro legato, of the legion VMacedonica. ${ }^{83}$ In his Ectaxis, of course, Arrian referred to several of his subordinates, but one can only guess whether he had appointed them himself and if so why. At any rate, the legate of the legion XV Apollinaris, M. Vettius Valens, ${ }^{84}$ had doubtless been assigned to that post by the emperor.

81 Literary evidence is given in A.R. Birley 1981, op. cit. (n. 15), 9 n. 22; epigraphic cases are listed ibid. 11. More names could be added, e.g. C. Cilnius Ferox under C. Cilnius Proculus, $A E$ 1946, 1, CIL 16. 46; M. Messius Rusticianus, tribune of XV Apollinaris and III Gallica, under his father-in-law. Cf. also the possible case of Tacitus, who might have served under his father-in-law Agricola, as conjectured by A.R. Birley, 'The life and death of Cornelius Tacitus', Historia 49 (2000), 230-247, at 237-238.

82 The diploma issued in July 122, CIL 16. 69, registers 13 alae and 37 cohorts in the army of Britain. On governors appointing equestrian officers see A.R. Birley, 'The commissioning of equestrian officers', in J.J. Wilkes, ed., Documenting the Roman Army (London 2003), $1-18$.

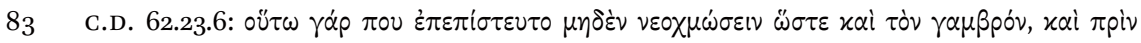

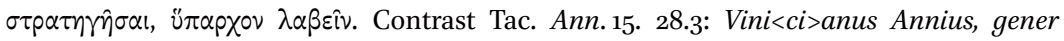
Corbulonis, nondum senatoria aetate et pro legato quintae legioni impositus. Cf. PIR ${ }^{2} \mathrm{~A} 700$.

84 Arr. Ectaxis 5 and 24. Valens' career is known from $C I L$ 11. 383, Ariminum. He had previously been iuridicus of Britain in the 120s or 130s-quite likely under Sextus Julius Severus - at a time when the governor was preoccupied with the military problems of 
It mostly has to remain a matter of speculation or informed conjecture as to what prompted army commanders in this period to choose their subordinates. The present paper has been an attempt to supply background information focusing on two episodes in a period for which the literary sources are poor but the epigraphic sources are copious. But it must be registered that the wars which took place under Marcus Aurelius and Lucius Verus, as well as the plague brought from the east by the returning legions after the end of Parthian War, and the resultant heavy losses among the elite, led to a change in the promotion patterns. This was to be revealed most strikingly by the careers of the future emperor Pertinax and of Marcus Valerius Maximianus, whose later career, not discussed above, was to be so remarkable. ${ }^{85}$ Thereafter the frequent executions of senators under Commodus and the civil wars of 193-197 led to further changes. But that is another story.

Vindolanda, 2015

that province; and he was patron of Britain: cf. A.R. Birley 2005, op. cit. (n. 15) 272-3 and $P I R^{2} \mathrm{~V} 494$.

85 On these two see Devijver, $P M E$ H 9 with his Supp. 1 and 2; $C P$, no. 181 bis; $P I R^{2}$ V 125; Alföldy 1987 , op. cit. (n. 74). 